\title{
The Profile of Students' Questions in Physics Lesson
}

\author{
Desi Fitria Wulandari \\ Universitas Pendidikan Indonesia \\ Bandung, Indonesia
}

\author{
Agus Setiawan \\ Universitas Pendidikan Indonesia \\ Bandung, Indonesia
}

\begin{abstract}
This study aims at investigating the students' question profile in learning physics at one of the high schools in Tasikmalaya. Three classes were chosen randomly at the same level. The students were asked to write down two questions in a certain time interval after a reading session. Judging from the structure of the question, on average, $47 \%$ of students questions were in category 1 (sentence actually asked). There were also $35 \%$ in category 2 (as a matter of complement) and $19 \%$ in category 3 (command line). Furthermore, $94 \%$ of the questions of students were closed questions and $6 \%$ of the questions of students were open questions. Overall $59 \%$ of the questions of students were included as factual questions and $41 \%$ as conceptual questions. Based on cognitive levels of Bloom's taxonomy, percentages of questions given were $38 \%$ remembering, $56 \%$ understanding, $4 \%$ application, $0 \%$ analysis, $0 \%$ evaluation and creation of $1 \%$.
\end{abstract}

Keywords—student questions; categorization of questions; learning physics

\section{INTRODUCTION}

Commitment to promote critical thinking skills has become one of the main agenda of education program in Indonesia. Secondary School Competency Standards mention that secondary school students are expected to: (1) establish and apply information or knowledge in a logical, critical, creative, and innovative, (2) demonstrate the ability to think logically, critical, creative, and innovative in decision-making; (3) demonstrate the ability to analyze and solve complex problems [1].

Based on a literature review, in order to improve students' critical thinking skills, a physics learning strategy base of asking activities and group competition (PLSAC) was proposed [2]. A study on the use of asking activities and group competition to enhance high school students' critical thinking skills on the topic of sound waves had been conducted. This article is an analysis of the profile of student's questions.

In learning process, the students should be able to ask questions. The question can be asked in order to get an explanation, as an expression of curiosity, or even just to get attention. Students are encourage to ask questions because this activity may promote learning and facilitate thinking [3]. It is as referenced in a constructivist, inquiry student role in the formation of knowledge.

Questions are a basic component of effective teaching [4]. The questions asked by the students play an important role in the learning process. But apparently, the students' ability to ask is still lacking. Farihah and Rahayu revealed that most of the questions asked by students in a question are on a low cognitive level (memorizing and understanding) [5, 6].

Mambay has conducted research to improve the skills of asking question through problem-based learning model and got a description of the ability to ask high school students. His research was completed to get the number of questions by 43 questions from 40 students. The questions asked by the students belong to the rote level $(\mathrm{C} 1)$ that are five students $(11.6 \%)$, the level of understanding (C2) as many as 21 students $(48.8 \%)$, the level of implementation (C3) in 1 student $(2.3 \%)$, analytical level (C4) as much as 9 students (20.9\%), and levels of evaluation (C5) were 7 students [7].

To analyze the question, the question need to be classified based on certain considerations. Widodo states, in the literature on the question, there are various classifications of questions, including: questions of academic and non-academic questions, closed questions and open-ended questions, questions related to cognitive processes as well as questions related to the knowledge dimension [8]. The literature has defined several classifications of questions.

a. References hamilton: questions of academic and nonacademic questions [8]. Academic questions are questions related to the subject matter, whether the material is past or the material being discussed. The questions are related to social, organization, discipline, and also are not related to the material are grouped in non-academic question.

b. Jones divided questions into two types, private and discussion. A private question was defined as a question with a single answer according to knowledge level, while a discussion question was open-ended with more than one appropriate answer [9].

c. Guilford divided questions into convergent and divergent. Convergent questions generally had one correct answer, as with multiple-choice questions, but divergent questions had many reasonable answers [10].

d. Hargreaves and de Rivera, Girolametto, Greenberg, and Weitzman classified questions as open- and closed-ended $[11,12]$. Closed questions are questions that only invite one or more responses. These questions are limited and usually go directly to one conclusion. Closed questions have a definite answer and limited. Meanwhile, openended questions are questions that invite a number of answers. These arein the case of open range of possible responses that can be given wider when compared to 
closed questions. open-ended questions requiring high cognitive skills such as inquiry and evaluation. closedended questions required lower level skills such as remembering. As all classifications were based on the scope and clarity of the expected answer, Jones's private question, Guilford's convergent question, and Hargreaves's and Riviera et al.'s open-ended questions all represent the same type of question. Similarly, Jones's discussion, Guilford's divergent, and Hargreaves's and de Rivera et al.'s closed-ended questions are the same [13].

e. The fifth is the questions related cognitive processes $[14,15]$. Dimensions cognitive processes include memorizing (remember), understand (understand), implement (apply), analysis (analyze), evaluated (Evaluate), and make (create).

- Memorizing (Remember) is the process of pulling back the information stored in long term memory. This category includes two kinds of cognitive processes: recognizing (recognizing) and remembering (recalling).

- Understanding (Understand): construct meaning or understandings based on prior knowledge possessed, or integrate new knowledge into existing schemes in students' thinking. This includea seven understanding cognitive processes: interpreting, exemplifying, classifying, summarizing, inferring, comparing and explaining.

- Apply (Apply): includes the use of a procedure to resolve the problem or task. This category includes two kinds of cognitive processes: running (executing) and implement (implementing).

- Analyze (Analyze): describes a problem or object to the elements and determine how the interplay between these elements. There are three kinds of cognitive processes included in the analysis: disjoint (differentiating), organizing (organizing), and find the implied message (attributting)

- Evaluating (Evaluate): make a judgment based on the criteria and standards. There are two kinds of cognitive processes include in this category: check (checking) and criticized (critiquing).

- Create (create): combine multiple elements into a form of unity. There are three kinds of cognitive processes that fall into this category, namely: making (generating), planning (planning), and producing (producing).

f. Questions related dimensions of knowledge include factual knowledge, conceptual knowledge, procedural knowledge and metacognitive knowledge.

\section{RESEARCH METHOD}

This study is a descriptive analysis of physics learning activities at one of the high schools in Tasikmalaya. Three classes were taken randomly at the same level. Third grade was a sample of the development of a learning model. The first class was a class of samples at the pilot phase. The second class was sampled at testing phase two. In addition, the third class was sampled on the main testing phase (validation) taken at its first meeting. Third grade had pursued the same conditions. Topics discussed at the third lesson of this class was about "sound".

Data collection method used was the learning document analysis. The learning document analysis of students' work was conducted in which the learning process taken place. This was conducted by asking the students to write down questions that they will ask during learning process. Those questions were asked on one session called tournament session in which students were asked to read out the questions that they created. Those questions were then answered by another group with a scoring system. Questions answered earned a certain point and the correct answer to this question also obtained the same point. The process was an exercise for the students to think and ask question during lesson.

\section{RESULTS AND DISCUSSION}

Data obtained from this study were in the form of written questions submitted by the student in the learning process. Not all the questions that they wrote can be filed in a tournament session because of the limited learning time.

\section{A. Analysis of the Quantity of Questions}

The first analysis was conducted on the quantity of questions that successfully made the students write two questions in five minutes given after reading the whole materials. The time given to read the teaching material was 15 minutes before the task was assigned to write the question and also by giving a chance to read outside the classroom before the lessons.

The quantity of the question illustrated their ability to construct queries. This did not pay attention to the quality of the resulting questions such as what the students write. In this analysis, it only counted how many meaningful sentences written questions that the students wrote on their task book.

In the first class, there were 30 students. Then, there were 32 students in the second class, whereas there were 31 students in the third class. Each student was asked to write down two questions and possible answers if they feel they are able to answer that question. Ideally, in the first class, it was expected that there were 60 questions in the first class, and 64 questions in the second class, and 62 questions in the last class. In fact, in the first class successfully created 45 pieces of questions $(75 \%)$, in the second class 50 pieces of questions $(78 \%)$ and in the third class as many as 49 pieces of questions (79\%). The overall quantity of questions students given was in an average of $77 \%$. This result of percentage of the quantity of student questions can be presented in Fig.1. The distribution of students according to the quantity of questions made is illustrated in Table I.

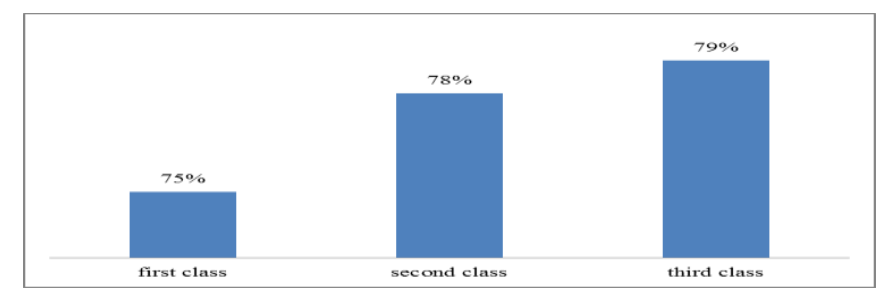

Fig. 1. Quantity Percentage of Students Question 
TABLE I. THE DISTRIBUTION OF STUDENTS ACCORDING TO THE QUANTITY OF QUESTIONS MADE

\begin{tabular}{cllll}
\hline Category & Description & $\begin{array}{l}\text { First } \\
\text { Class }\end{array}$ & $\begin{array}{l}\text { Second } \\
\text { Class }\end{array}$ & $\begin{array}{l}\text { Third } \\
\text { Class }\end{array}$ \\
\hline A & $\begin{array}{l}\text { Able to make two or } \\
\text { more of the }\end{array}$ & $\begin{array}{l}18 \text { of } 30 \\
(60 \%)\end{array}$ & $\begin{array}{l}20 \text { of } 32 \\
(63 \%)\end{array}$ & $\begin{array}{l}21 \text { of } 31 \\
(68 \%)\end{array}$ \\
& questions & & & 7 of 31 \\
& Able to create 1 & 9 of 30 & 10 of 32 & $(22 \%)$ \\
\hline question & $(30 \%)$ & $(31 \%)$ & 3 out of \\
& $\begin{array}{l}\text { Not being able to } \\
\text { make a single } \\
\text { question }\end{array}$ & $\begin{array}{l}3 \text { of } 30 \\
(10 \%)\end{array}$ & & $31(10 \%)$ \\
\hline
\end{tabular}

Overall the students who enter the a category are $64 \%$, $28 \%$ are in b category, and $9 \%$ is in c category. More detailed data can be seen in Fig. 2.

\section{B. Analysis of the Structure of the Question}

Having analyzed the quantity of student questions, the structure of the question was analyzed. As stated by Rustaman, the question sentence should begin with question words. In fact, the questions made by the students in this analysis consist of three categories: (1) in the form of a sentence of questions that begin with the interrogative sentence, (2) in the form of a fragment of which ends marked points (much like a matter of completing the exam ) and (3) in the form of a sentence order (starting with explain, list and said other commands) [16].

Based on the results obtained by analysis of the average student question $47 \%$ in the category (1), 35\% in the category (2) and $19 \%$ in category (3). The percentage of questions that the students based on the structure of the question in each class can be seen in the Fig. 2.

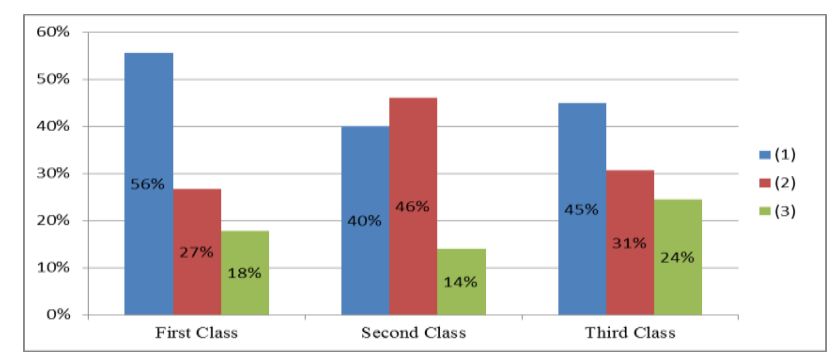

Fig. 2. Structural Analysis of Student Question

\section{Closed-Open Question}

Student questions were analyzed based on the likelihood of expected answers to these questions. Based on analysis of the closed-open type of question, it can be seen that overall $94 \%$ of the questions of students are closed questions and $6 \%$ of the questions of students are open question. In the first class, there are 43 of the 45 questions (96\%) questions which builds students' knowledge were closed question while the remaining two questions (4\%) were open questions. In the second class, 47 to 50 questions (94\%) which builds students' knowledge were closed while the remaining three questions $(6 \%)$ were open question. In the third class, 46 of the 49 questions (94\%) questions which builds students' knowledge were closed while the remaining three questions $(6 \%)$ were open question. More detailed data which is the percentage of each type of question in each class can be seen in Fig.3.

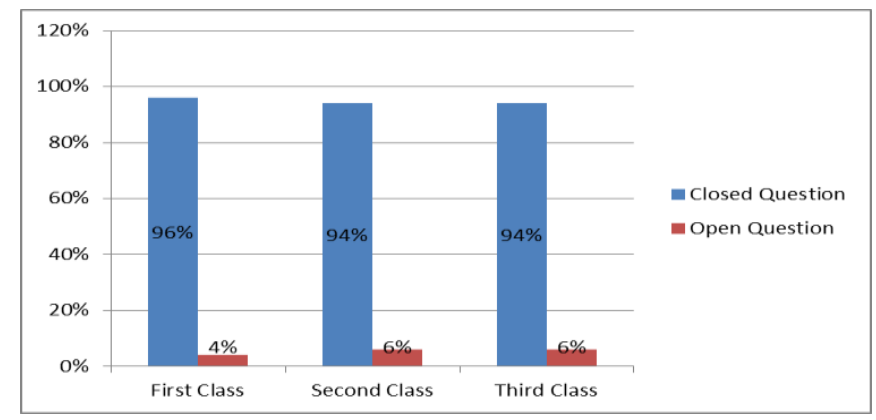

Fig. 3. Types of question by students: Closed/Open question

\section{Knowledge Type in Question}

The analysis of questions based on the type of knowledge that was asked revealed that the type of knowledge of the most widely asked was factual knowledge and conceptual knowledge. None of the questions was about procedural knowledge and metacognitive knowledge. Overall, 59\% of the questions of students were included as factual questions and $41 \%$ were included as conceptual questions.

Fig.4 shows in first class, there were 25 questions (56\%) including questions about the factual knowledge and 20 questions (44\%) about conceptual knowledge. In the second class, there were 32 questions (64\%) including questions about the factual knowledge and 18 questions (36\%) about conceptual knowledge. Meanwhile, there were 28 questions (57\%) including questions about the factual knowledge and 21 questions $(43 \%)$ about conceptual knowledge in the third class.

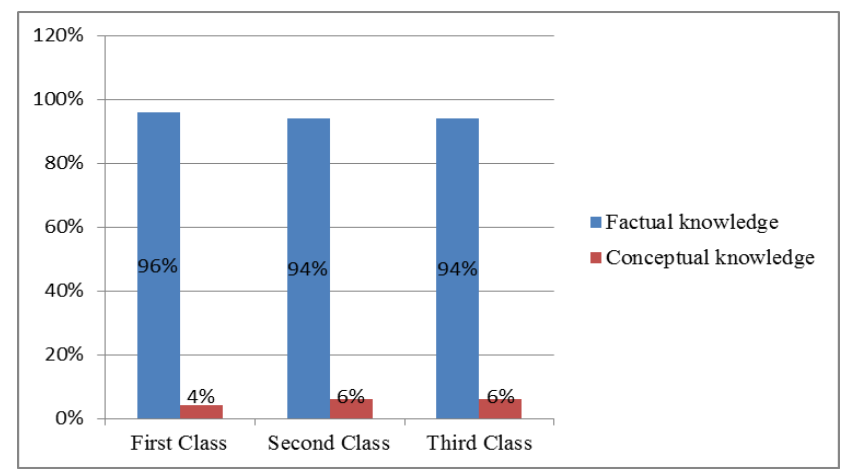

Fig. 4. Students' question classified by Type of Knowledge

\section{E. Study Cognitive Taxonomy}

Based on the analysis of cognitive Bloom's taxonomy, it was acquired that $38 \%$ questions were about remembering, $56 \%$ understanding, $4 \%$ application, $0 \%$ analysis, $0 \%$ evaluation, and $1 \%$ creating. More detailed data can be seen in Fig. 5. 


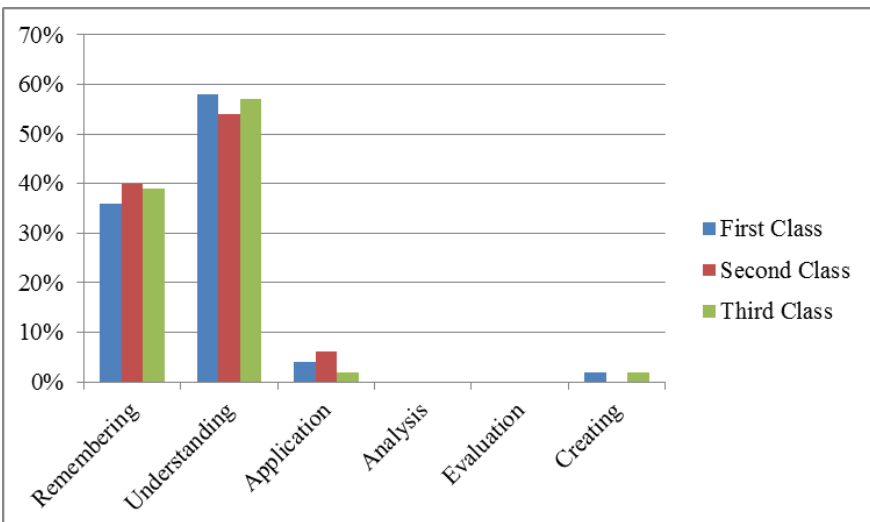

Fig. 5. Classification of students' question based on cognitive level

The document analysis of learning process occurs in the classroom showed that during the learning process the students had the ability and willingness to ask. The results confirmed prior studies that most of the questions asked by the students were low cognitive level questions (memorizing and understanding) [5,6]. However, the result was different from that obtained by Mambay which showed that the questions asked by students almost evenly spread of low-level cognitive processes question to question high-level cognitive processes [7]. This study revealed that students were using the question in an effort to better understand the concepts.

\section{CONCLUSION}

The study revealed that the students were keen and able to ask during the learning process. Further analysis of the question showed that most of the questions asked by the students were still incorrect when judged based on their sentence structure. The students' questions were mostly closed-ended questions, such as the type of factual and procedural knowledge. Furthermore, most of the questions asked by the students were still in a low cognitive level (memorizing and understanding). These results indicated that various method need to be exercised in order to improve students' asking skill.

\section{REFERENCES}

[1] Peraturan Mendiknas No. 23. Standar Kompetensi Lulusan untuk Satuan Pendidikan Dasar dan Menengah. Jakarta : Departemen Pendidikan Nasional. 2006.

[2] Fitria, Desi. Physics of Learning Strategy to Train Critical and Creative Thinking Skills. International Journal of Science and Research (IJSR), 2014. Volume 3 Issue 11, November 2014.

[3] Dillon, J. T. The Remedial Status of Student Questioning. Journal of Curriculum Studies, 1988, 20 (3), 197-210..

[4] Bell, L. I. Strategies that Close the Gap. Educational Leadership, 2002, 60 (4), 32-34.

[5] Farihah, I. Profil Pertanyaan Siswa SMU dalam Proses Belajar Mengajar Biologi. 1997. Tesis Biology Faculty FPMIPA UPI: unpublised.

[6] Rahayu, E. Keterampilan siswa SMU dalam Mengajukan Pertanyaan Tertulis pada Konsep Alat Indera. 2001. Tesis Biology Faculty FPMIPA UPI: unpublised.

[7] Mambay, E. Penerapan Pembelajaran Berbasis Masalah untuk Meningkatkan Penguasaan Konsep, Sikap Ilmiah, dan Kemampuan Bertanya Siswa SMA pada Topik Keanekaragaman Hayati. 2010. Dissertation IPA UPI: unpublised.

[8] Widodo, A. Profil Pertanyaan Guru dan Siswa dalam Pembelajaran Sains. Pendidikan dan Pembelajaran Journal, 2006, 4(2), 139-148.

[9] Jones, T. C. An in-depth analysis of presentation styles, information technology usage, questions strategies, and teacher and student evaluations in interactive telecourses (Doctoral dissertation). 1995. The University of Alabama, Tuscaloosa, Alabama.

[10] Guilford, J. P. The structure of intellect. Psychological Bulletin, 1956, 53(4), 267-293.

[11] Hargreaves, D. H. Teachers' questions: Open, closed and half-open. Educational Research, 1984, 26(1), 46-51

[12] de Rivera, C., Girolametto, L., Greenberg, J., \& Weitzman, E. Children's responses to educators' questions in day care play groups. American Journal of Speech-Language Pathology, 2005, 14(1), 14-26.

[13] Melike Aydemir, Engin Kurşun \& Selçuk Karaman. Open Praxis, vol. 8 issue 1, January-March, 2016, pp. 9-19.

[14] Bloom, B.S. Taxonomy of Educational Objectives, Book 1: Cognitive Domain. London: Longman. 1971.

[15] Anderson, L. W., Krathwohl, D. R., Airasian, P. W., Cruikshank, K. A., Mayer, R. E.,Pintrich, P. R., et al.. A Taxonomy for Learning, Teaching, and Assessing: A Revision of Bloom's Taxonomy of Educational Objectives. New York: Longman. 2001.

[16] Rustaman, A., and Rustaman, N. Peranan Pertanyaan Produktif dalam Pengembangan KPS dan LKS. Departemen Pendidikan Nasional. Bandung. 2003. 